\title{
The More Things Change, the More They Are the Same: Continuing Concerns With the Special Olympics
}

\author{
Keith Storey \\ Touro University
}

The Special Olympics has been a controversial program for persons with severe disabilities. There have been numerous discussion articles in the literature concerning pros and cons of the Special Olympics, and research has often found negative results concerning the Special Olympics: The purpose of this article is to review and to discuss concerns regarding the Special Olympics as well as to suggest future directions for recreational services for individuals with severe disabilities.

DESCRIPTORS: inclusion, integration, recreational services, best practices, intellectual disabilities

Despite decades of research, advocacy, and program development, most adults with severe disabilities live lives of segregation. This segregation is across the board in work, community, and recreational settings. Perhaps most surprising is the segregation in recreational scttings that would appear to be the easiest area in which to achieve integration. Several factors have been suggested to explain why this segregation in recreational settings occurs; for example, funding, lack of integrated services, lack of individual skills, and lack of appropriate supports.

One factor that may strongly influence this segregation is the Special Olympics. Concerns with the Special Olympics have been discussed in the literature for 30 years. Despite the decades of concern, the program continues and receives more and more funding and increases in the number of participants (200 million worldwide in 2000 ). The continuation of this program and the increases in the number of participants of course foster the increased segregation of individuals with severe disabilities.

Although researching and promoting inclusive recreational options are extremely important, it is also necessary to analyze segregated programs such as the Special Olympics to better understand why they do not work and how they impede the implementation of integrated services.

The issues around the Special Olympics are perhaps best reflected by the quote from Alphone Karr, "The more things change, the more they are the same" (Les Guêêpes, January 1848). This was highlighted recently

Address all correspondence and reprint requests to Dr. Keith Storey, College of Education, Touro University, 1310 Johnson Lane, Mare Island, Vallejo, CA 94592. E-mail: kstorcy@touro.edu by the remark by President Barack Obama on the nationally televised Jay Leno show (March 19, 2009) in which he remarked in regard to his bowling skills, "It was like the Special Olympics or something." The response regarding this remark received prominent coverage in the mainstream media and further enhanced the general public's perception of people with severe disabilities through the lens of the Special Olympics.

The purpose of this article is to highlight concerns that have been raised regarding the Special Olympics so that practitioners and others have a clearer understanding of the concerns and can use this information to advocate against the Special Olympics and other segregated programs and for integrated recreational services.

\section{What Is Integration in Recreational Settings}

First, it is important to define what is meant by integrated recreational services as the Special Olympics often claims that their programs are integrated. Social integration has been defined as "regular access to interactions with individuals without identified handicaps and regular use of normal community resources" (Will, 1984). Mank and Buckley (1989) described integration as "in its simplest and most elegant form as a degree of community presence and participation for persons with disabilities that is no different from that enjoyed by persons without a disability labcl." Four different components of integration have generally been considered: physical integration, social integration, relationships, and social networks (Mank \& Buckley, 1989; Storey, 1993).

Ford and Davern (1989) noted that integration is a complex social phenomena and that it is easier to describe what it is not than what it is. This relates to the Special Olympics as it is easier to describe the segregation that it represents more than what integrated services are.

Chadscy (2007) points out that people arc more likely to form a relationship with someone if there is frequent exposure and if they know that there is a high probability of future interactions with the individual; if future interaction is unlikely, then the amount of effort devoted to that relationship will probably be smaller. Social interactions that do occur between persons with and without disabilities at the Special Olympics are likely to be short 
term (a brief meeting between the volunteer and the person with a severe disability) and unlikely to develop into friendships or social networks.

Smart (2001) reviews research which indicates that superficial and casual interactions, such as those that occur in the Special Olympics between persons with and without severe disabilities, do not lead to a reduction in prejudice and may actually reinforce negative stereotypes regarding people with disabilities. As noted by Johnson (2003), events such as the Special Olympics foster the "us against them" attitude (with the "them" being people with disabilities) and that there has been a backlash against disability rights in part due to people with disabilities being in segregated settings and events and not being part of the mainstream society (e.g., becoming the "us" rather than the "them").

There is no way around it; the Special Olympics is a segregated event (Hourcade, 1989; Wolfensberger, 1995). You can participate only if you have a disability, and, as such, you have the major problem facing the program. At best, the Special Olympics provides mere physical presence with nondisabled persons. It was designed in a time (1968) when segregated programs were the norm and the idea was to develop recreational services for individuals with severe disabilities that were separate from those for nondisabled people (Polloway, Smith, Patton, \& Smith, 1996). Although what is considered "best practices" in the recreational area have changed dramatically since 1968 (Dattilo, 2008; Stumbo \& Peterson, 2009), the basic premise of the Special Olympics has remained the same.

\section{Reinforcement of Negative Stereotypes}

President Obama's remark highlights how the Special Olympics reinforces negative stereotypes of people with disabilities. Popular press accounts of the Special Olympics often reinforce a negative self-fulfilling prophecy that evokes sympathy, pity, or stigma and promote negative stereotypes of people with disabilities (Polloway \& Smith, 1978; Shapiro, 1993; Wolfensberger, 1995). Here are a few examples:

Chad McFarlane, 13, of Medford triumphs over retardation and his own hesitance in cross-country skiing at the Special Olympics. Part of a worldwide network, the Oregon games this year drew about 400 athletes who suffer from mental retardation to Mount Bachelor during the weekend to ski, skate and even dance just for fun at a party in Sunriver (Ellis, 1989).

Suppose behind the vacant, empty eyes, the gold medal on the red, white and blue ribbon dazzled them and meant something. Is it possible that the mouth that could not control saliva was willed by the brain to smile, but the muscles just couldn't do it? (Bombeck, 1987).
The Pittsburgh Press had a picture of a person being hugged with caption, "Special Hug" (Mellon, 2000).

Syracuse Herald-American said that it was difficult "deciding where the 'special' ends and the 'Olympics' begins" (Brieaddy, 1993).

An editorial in the same paper noted that Special Olympics volunteers learn that "the mentally retarded are 'great kids'" (A gift, 1993).

A headline in the Oakland Tribune remarked "Special Olympics' Athletes Win Smiles: Races belong to not-so-swift, not-so-strong" (Gardiner, 1998).

But the real stars of the show were the event participants who, despite their mental handicaps, were able to inspire all who attended, as well as conjure up smiles from all the warm huggers and event contributors (The Union-Recorder [Milledgeville, GA, April 9, 2009]).

Each of these examples reinforces negative stereotypes of people with disabilities through their descriptions and use of language, especially a phrase like "suffers from...." (Blaska, 1993; Longmore, 1985). These examples are consistent with the analysis by Smart (2001) in that language used by the broader society to speak about devalued people has the following characteristics: (a) the words used to describe these people are both offensive and demeaning; (b) the identifying words that are used to set these people apart from the broader society make very clear that these people do not "belong" with everybody else (this is called "distancing" or "polarization"); (c) usually the language is not a self-identification - people do not use these terms to describe themselves; (d) the language usually "lumps" all the people perceived to be in the group together, regardless of individual differences; (e) the labels used to describe people with disabilities describe, often inaccurately, only one aspect of an individual's identity ("this is called reductionism"); and (f) society is very reluctant to change individual language use, using the defense of ease of use or of freedom of speech (p. 56).

\section{Lack of Functional Skills}

Functional curricula consist of teaching skills that have direct and immediate utility in persons' lives within their communities and contribute directly to the attainment of greater independence, self-sufficiency, and quality of life (Brown et al., 1979; Brown, Nietupski, \& Hamre-Nietupski, 1976). A basic analysis of functionality is whether an individual who does not learn to perform a particular activity needs to have someone else do it for him or her? If the answer is "yes," the activity is likely to be functional. Many of the Special Olympics events are of doubtful functional value and do not prepare people for the 
criterion of ultimate functioning (Block \& Moon, 1992; Orelove, Wehman, \& Wood, 1982). How functional are some events, for example, the softball throw where the participant throws to a spot on the ground, rather than to a person? It is important to note that form refers to a specific motor act whereas function focuses on the outcomes that the activity achieves (Brown, Evans, Weed, \& Owen, 1987). Thus, it is possible to teach a skill that achieves a certain form (passing a basketball) but does not achieve the function (the person is unable to pass a ball quickly and accurately to teammates during a basketball game).

Brown et al. (1976) have suggested a series of questions regarding functionality to ask of any activity or skill being taught to individuals. These include the following: "Could students function as adults if they did not acquire the skill? Is there a different activity that will allow students to approximate realization of the criterion of ultimate functioning more quickly and more efficiently? Will this activity impede, restrict, or reduce the probability that students will ultimately function in community settings?" (p. 9). The Special Olympics events are unlikely to have a positive impact on these areas.

In the Special Olympics, there is a lack of skill acquisition, and much precious teaching time of functional activities is lost. For example, one newspaper article reported that "Many of the athletes spent two days a week for the past eight months training for the event" in which many persons participate once a year (Gardiner, 1998).

\section{Age Inappropriateness}

Age-appropriate curriculum and materials involve materials and activities that are consistent with a person's chronological age (McDonnell, Mathot-Buckner, \& Ferguson, 1996). As noted by Wilcox and Bellamy (1982), because the goals of best practices are in part to minimize the discrepancies between individuals with and without disabilities, educational arrangements that exaggerate or highlight deviance labels should be avoided and that age-inappropriate activities and materials stigmatize the individual with a disability. Studies by Bates, Morrow, Pancsofar, and Sedlak (1984) and Calhoun and Calhoun (1993) found that chronological age-appropriate activities have a positive effect on how a person with a disability is perceived by others and that the use of ageinappropriate activities decreased the positive perceptions of people without disabilities toward individuals with severe disabilities.

The adult participants in the Special Olympics are often perceived as children because both children and adults compete at the same event that often leads to the infantilization of adults with disabilities. This infantilization leads to participants being denied adult status and dignity (Fleischer \& Zames, 2001; Smart, 2001). This has especially been reflected in newspaper reports of the Special Olympics. Each of the following articles labels adults with disabilities as children, thus reinforcing this stereo- type for the general public. The impact of these articles may be long-term in how the general public views adults with severe disabilities.

"It just proves that something can be done for these children," said Doreen Selekanc, one of the volunteers (DePalma, 1997).

The event gives kids the chance to compete (Cowles, 1998).

Special Day for Special Kids. About 200 people between the ages of 3 and 50 competed in the event (Special Day, 1999).

Rogers [intern director of Ventura County's Special Olympics] said she and her co-workers cry every year at the ceremonics. "It's the spirit and excitement," she said. The kids have just given their all (Suman, 1999).

In 2007, at the California Special Olympics state games, recreational areas for participants were numerous booths and games such as clown toss, ring toss, and "golf" with plastic clubs and balls. Prizes included stickers, costume jewelry, and children's toys. General public members at the event (including employers, neighbors, members of the media) are likely to thus view the adults with severe disabilities as children rather than as adult members of society and as potential employees, friends, etc.

\section{Financial Concerns}

Previous writings have raised concerns about how the money for the Spccial Olympics is raised and spent such as money being spent on cars and apartments for senior staff (Storey, 1998, 2004). There are only general guidelines for appropriate levels of compensation in nonprofit organizations, and it is appropriate to have salaries that attract and keep competent personnel (Lampkin, 2006; Vogel \& Quatt, 2005). The salaries for the Special Olympics may be appropriate or not depending upon one's perspective, but here are a few points to consider in evaluating them.

A look at the 2007 Internal Revenuc Service 990 reports (the most recent available at the time of writing) shows continued concerns in this area. For that year, $\$ 11,865,020$ was spent on salaries by the national office (with an additional $\$ 498,520$ in pension plan contributions and $\$ 1,599,923$ in employee benefits). The Special Olympics pays 58 employees more than $\$ 50,000$ per year (this is the national office and does not include state or international chapters). The salary for the five highest paid employees other than officers, directors, and trustees ranged from $\$ 163,984$ to $\$ 210,797$ (plus benefits ranging from $\$ 13,119$ to $\$ 19,634$ ). Salaries for officers include $\$ 229,652$ for the chief administrative officer, $\$ 294,671$ for 
the chief executive officer, $\$ 158,066$ for the senior vice president of finance, $\$ 231,920$ for the chief legal office, $\$ 147,381$ for the chairman, and $\$ 136,188$ for the general counsel. The compensation of the five highest paid contractors also raises concerns with $\$ 1,041,903$ being spent on two direct marketing firms, $\$ 178,179$ to an information technology support firm, and $\$ 283,784$ for consulting. The international board of directors is identified as being a "volunteer" board, yet two of its members received compensation of $\$ 28,000$ and $\$ 16,000$. State chapter officers are also well compensated. For example, the Northern California Special Olympics vice president has a salary of $\$ 150,000$ plus a $\$ 6,406$ expense account.

As previously researched (Storey, 1998), the Special Olympics has used for profit direct marketing firms where little of the money raised actually goes to the charity and in some cases the charity actually loses money. For example, the Northern California Special Olympics in 2006 paid $\$ 901,683$ to one fundraiser (The Heritage Company).

\section{Use of Tax Payer Dollars}

Money spent on the Special Olympics involves not only individual and corporate contributions but also money from federal funds. In 2007, the Special Olympics received $\$ 6,961,677$ in government grants. The Special Olympics Sport and Empowerment Act (HR5131), which was signed into law in 2004, authorized $\$ 15$ million in funding per year for more than 5 years $(\$ 4.4$ million in fiscal 2008 appropriations) "... for the growth of Special Olympics Programs in communities across the United States and around the world." The Special Olympics also has their own funding category (CFDA\#84.380) through the Office of Special Education and Rehabilitative Services. In the fiscal year $2008, \$ 11,790,360$ was available in noncompetitive awards.

\section{Paternalism}

An important component of the disability rights movement has been that people with disabilities control the service system and the Special Olympics is in contrast to these developments (Charlton, 1997; Fleischer \& Zames, 2001; Shaw, 1994; Turnbull, Stowe, Turnbull, \& Schrandt, 2007). Of the 36 member of the 2008 Special Olympics international board of directors, only one is identified as having a developmental disability and no others are identified as having a disability of a different type. With other athletic competitions involving persons with disabilities (Deaf Olympics and Paralympics), people with disabilities are in control of the organizations and activities. With the Special Olympics, people with disabilities are "receiving" services whereas those with decisionmaking power are people without disabilities.

\section{Coach Is in Dominant Role}

In sports, the coach is expected to direct players as to what they are to do. In the Special Olympics, the coach is a person without a disability and this means that the athletes are in a subordinate role of being less able, more dependent, and unequal. This arrangement makes it difficult to establish friendships and social networks between participants with severe disabilities and nondisabled coaches (e.g., the coach-athlete relationship). Research has found that equality is a key ingredient to forming relationships (Amado, 1993; Newton, Olson, Horner, \& Ard, 1996), and this equality is not found in the Special Olympics.

\section{The Huggers}

The "huggers" at the Special Olympics have been a problem throughout its history. For example, the Miami Herald ran an article (February 13, 2009) in which the text was, "Wanted: hundreds of excellent huggers in the South Florida area. The Miami-Dade Special Olympics is in need of 2,000 volunteers, or huggers..." The Arizona Republic (May 21, 2008) had a letter to the editor in which the writer said of his volunteer experiences at the Special Olympics, "I was allowed to present the medals for which I received a bounty of hugs and a few kisses." A New York Times article had a picture of a person being hugged with the caption, "The second-place winner in a 3,000 meter run, Ludmila Kanushevskaj of the Ukrainian team, got a hug from Rose Marie Spatafore, who with Rose Carotenuto had come from Ansonia, Conn. to watch the games" (Martin, 1995). The Fresno Bee quoted two Special Olympic directors as saying "We get paid," says Carolyn "All the smiles and hugs we can get." "We're big huggers," says her husband. "The kids love it. So do we" (Barberich, 2001). President George W. Bush, at a Special Olympics Global Law Enforcement Torch Run Ceremony at the White House (Whitehouse.archives.gov; July 6,2007 ), stated that

I remember when I was Governor of the great State of Texas being a hugger. That was during the Special Olympics games. If you've never been a hugger, I strongly advise you to be one. [laughter] That means you stand at the end of the finish line of a race and you hug the people coming across the line. It meant a lot to me to be a hugger.

After President Obama's remark about the Special Olympics on the Tonight Show, U.S. Representative. Patrick J. Kennedy (nephew of Eunice Shriver) said, "But the best way to apologize is to go to a Special Olympics event and be a 'hugger."

Not only does the presence of the huggers reinforce the infantilization of adults with severe disabilities, they also reinforce the belief that people with disabilities need to be "helped" by nondisabled people. Also, individuals with severe disabilities may often have difficulties engaging in appropriate social behavior (Carter \& Hughes, 2007; Hanley-Maxwell, Rusch, Chadsey-Rusch, \& Renzaglia, 
1986). So here you have athletes being hugged by complete strangers. The huggers set up a dilemma of reinforcing inappropriate social behavior where participants are encouraged to hug strangers. This can be especially problematic if participants generalize this behavior to other settings and situations.

\section{Choice and Self-Determination}

Choice and self-determination have become an integral part of instruction and support for individuals with severe disabilities (Agran, King-Sears, Wehmeyer, \& Copeland, 2003). Choice has been defined as "the act of an individual's selection of a preferred alternative from among several familiar options" (Shevin \& Klein, 1984). Choice requires alternatives. Informed choice means that "useful information is provided in a clear and understandable manner about two or more reasonable options or the person has experience or the opportunity to gain experience to understand the benefit or risk of the options. If necessary, a person must be supported through education, role modeling and accommodation to have informed choice" (www.self-determination.com).

The nondisabled people who run the Special Olympics often advocate that it is the choice of the participants and that they prefer the Special Olympics over other recreational options. This has often been the position of others who run segregated programs like institutions or sheltered workshops (Crissey \& Rosen, 1986, Voice of the Retarded Web site). The Special Olympics is an example of the "Disability Industrial Complex" where "the system" is vast and often self-serving to professionals (Dileo, 2007). In addition, as Heshusius (1984) points out, "The fact remains, however, that many of those placed in segregated settings do not have the freedom to refuse."

It is not clear how many individuals participating in the Special Olympics are making an informed choice to participate or have alternative choices available with appropriate supports.

True choice depends on having preferences, information, options, and control (Callahan \& Mank, 1998). Because many people with severe disabilities have limited experiences in integrated recreational settings, they may not be able to make a truly informed choice. An individual has to be aware of and to have access to choices. In most communities, it is easier to "choose" a segregated program as these are often more readily available than integrated programs, and individuals with severe disabilities are often more likely to have had experience in those segregated programs than in integrated programs. The individual also then needs appropriate supports. One may make a choice to participate in a city softball league, but if they cannot get to and from the games and will not have appropriate supports during the games, then the choice becomes meaningless.

When individuals are given the opportunity to choose between doing something or not, these are not true choices. Research in employment indicates that people with severe disabilities do not choose segregated options when presented with multiple alternatives, even when expressing some levels of satisfaction with current segregated programs (Butterworth, Fesco, \& Ma, 2000; Rogan, Banks. \& Howard, 2000). Mank (2007) points out that limited exposure to alternatives and experiences translates into limited understanding of possibilities and choices. Thus, it is unfair to say that it is the person's choice to go bowling with the Special Olympics on Saturday when it is either that or nothing. Integrated recreational choices may be limited in part because funding is more likely to go to the Special Olympics. Discussing a survey of Special Olympics participants, Harada and Siperstein (2009) advocated for greater opportunities and choice for sport programming for individuals with intellectual disabilities. It is also interesting that their results found that $48 \%$ of active athletes in the Special Olympics engaged in three or more hours of leisure-time physical activity per week outside of their participation in the Special Olympics.

\section{Lack of Empirically Verifiable Lifestyle Outcomes From the Special Olympics}

Changes in service delivery systems have led to a focus on individuals with severe disabilities leading socially valued lifestyles involving community integration, social relationships, skills development, choice, and selfdetermination (Felce \& Perry, 2007). It is possible to analyze programs in terms of their ability to deliver lifestyle outcomes from the six quality-of-life domains (i.e., physical well-being, material well-being, social well-being, productive well-being, emotional wcll-being, and civic well-being) as suggested by Felce (1997).

There has been very little research concerning the Special Olympics, and there is no research suggesting that the Special Olympics is effective in providing quality-of-life outcomes (as outlined by Felce, 1997) for participants. The few published studies show limited or mixed results at best (Brundige, Hautala, \& Squires, 1990; Dykens \& Cohen, 1996; Gillespie, 2008; Klein, Gilman, \& Zigler, 1993; Lord \& Lord, 2000; Ninot, Bilard, \& Sokolowski, 2000; Weiss \& Bebko, 2008; Wilhite \& Kleiber, 1992). It is important to note that there are no studies finding that the Special Olympics is more effective than integrated recreational programs in providing desired quality-of-life outcomes.

\section{Negative Outcomes From the Special Olympics}

There have been several studies that have reported negative outcomes from the Special Olympics. These studies have included volunteers and perceptions of the general public. In two studies, Roper (1990a, 1990b) found that perceptions toward people with severe disabilities did not change in a positive direction because of contact as a volunteer at the Special Olympics and that certain features of the event in fact reinforced negative perceptions. 
Porretta, Gillespie, and Jansma (1996) assessed perceptions of various agencies and organizations regarding the Special Olympics. Among their results was the overall recommendation of the respondents that the Special Olympics needed to change its mission to place more emphasis on integration.

Storey, Stern, and Parker (1990) found that a person portrayed in Special Olympic activities was perceived to be less competent than the same person portrayed in matched integrated community activities. The respondents regarded the woman in the Special Olympic events as younger and felt that she should be in more segregated school and recreational settings.

Burns, Storey, and Certo (1999) found that high school service learning students who volunteered at the Special Olympics did not have a change in their attitudes toward persons with severe disabilities because of their participation. Indeed, they had more negative attitudes toward students with severe disabilities than nondisabled high school students involved in integrated service learning activities.

\section{Promotion of Handicapism}

Handicapism is a theory and set of practices that promote unequal and unjust treatment of people due to apparent or assumed physical or mental disability (Bogdan \& Biklen, 1977; Bogdan \& Knoll, 1995; Smart, 2001). Because the Special Olympics is designed to serve only persons with disabilities, it focuses the attention of the public on the disability rather than the person. Therefore, the Special Olympics perpetuates the belief that there are two classes of people-"normal" and "disabled"-and that people with disabilities need a recreation program different from that provided to persons without disabilities (Orelove \& Moon, 1984).

\section{Promotion of Corporations}

As an illustrative case study, the South Central Area 6 Special Olympics in Wisconsin offers corporations six types of sponsorships (i.e., State Games Partner, Polar Plunge Partner, Law Enforcement Torch Run Partner, Preferred Provider Partner, Cause Marketing Partner, and Specific Event Sponsor). These sponsorships are advertised thus, "If your company is looking for a way to exponentially raise its sales bar, increase company exposure, and affiliate itself with the world's most credible charity, this is it!" (www.specialolympicswisconsin.org/ corporate_partners.html).

There is also promotion offered in the "World's Largest Truck Convoy, Wisconsin Partnership Opportunities," in which the $\$ 15,000$ Presenting Partnership includes

- Up to 25 convoy entries, including one placed as VIP lead truck.

- Presenting sponsor status "World's Largest Truck Convoy for Special Olympics Wisconsin presented by (you)."
- Right to use Special Olympics and Truck Convoy logos in advertising.

- Company recognized with award at the celebration party, with lunch for the corporate representative and/ or drivers.

- Company logo or name on all marketing materials, including T-shirts, event programs, Web site, press releases, event banners, registration letters, and radio advertisements

- Opportunity to include company information or items in the participant goodie bags.

At no point in the corporate advertising or in the recruitment of corporate sponsorship is there any mention of actually hiring individuals with severe disabilities. So the point of the promotion becomes increased profits for the corporation and enhancement of their corporate image, not the employment of individuals with disabilities that helps to contribute to the high unemployment rate among adults with severe disabilities. (Why should I hire them when I give to their charity?) The national Special Olympics Web site link for "corporate partners" says "For marketers of global businesses and for brands interested in building awareness and growth, Special Olympics is the right partner." Again, no mention of hiring people with severe disabilities.

\section{Discussion}

There are three overall choices regarding the Special Olympics in terms of what, if anything, should be done. The first would be "no change" and to keep the current structure in place. However, in regard to the arguments discussed in this article, this does not appear to be a viable (or socially acceptable) option.

The second would be to reform the current structure but to keep the basic premise and conditions of the Special Olympics. However, because the premise of the Special Olympics is unacceptable in regard to perpetuating the segregation of people with severe disabilities and is not in keeping with best practices in the field, this option is not desirable. As noted by Orelove et al. (1982), "Many traditions in our culture are valuable and inspirational; however, when tradition infringes long-range social habilitation of a group of citizens ... its benefits wane considerably" (p. 329). From a systems change perspective, it does not appear to be logical to keep a dual system in place for recreational services for people with severe disabilities in which one system promotes segregated services and the other integrated services (Lipsky \& Gartner, 1997; Schleien \& Meyer, 1988).

The third option would be to discontinue or replace the Special Olympics with programs in inclusive recreational leisure situations (Moon, 1994). Over the past 40 years, what is considered best practices has changed from facilities to programs and then from programs to supports (Hagner, 2000). Attitudes toward the participation of people with severe disabilities into integrated recreational 
programs are often quite positive (Kozub \& Lienert, 2003; Siperstein, Glick, \& Parker, 2009; Townsend \& Hassall, 2007).

As noted by Smith, Edelen-Smith, and Stodden (1998), changing from the "old ways" to the "new ways" means taking away the familiar with the understanding that these changes can be difficult but that it is important to question the basic assumptions upon which program and service systems are organized. Some authors have suggested concepts such as the "Kennedy games" (Hourcade, 1989 ) or the "National Youth Olympics" (Rice \& Flcck. 1988), where there is a formalized structure for integrated recreational services. There is an extensive empirical research base which indicates that individuals with severe disabilities can be successfully included in integrated recreational settings with appropriate supports (Dattilo, 2008; Kozub \& Porretta, 1996; Moon, 1994; Zhang, Gast, Horvat, \& Dattilo, 1995). The continued support of segregates services limits the availability of more inclusive services (Anderson \& Heyne, 2000).

An increasing research base indicates that services and supports in typical recreational settings may be the best way of achieving meaningful quality-of-life outcomes for persons with disabilities (Dattilo, 2008; Devine, McGovern, \& Hermann, 1998; Schleien, Green, \& Heyne, 1993). As person-centered planning and selfdetermination become more prevalent, individually planned and supported recreational placements may replace more group and center-oriented services such as the Special Olympics (Browder, Cooper, \& Lim, 1998; DiLeo, 1994; Garcia \& Menchetti, 2003; Modell \& Valdez, 2002; Wehmeyer, Agran, \& Hughes, 1998). The key point to consider is that segregated programs like the Special Olympics do not work and cannot be reformed (Dileo, 2007). Like all segregated programs, the Special Olympics is unable to deliver important quality-of-life outcomes for people with severe disabilities and often diminishes the possibility of achieving those outcomes. So why continue it? Let us replace it with integrated recreational services.

\section{References}

A gift for spectators, volunteers. (1993, May 10). Syracuse HeraldAmerican, p. A8.

Agran, M., King-Sears, M., Wehmeyer, M. L., \& Copcland, S. R. (2003). Student-directed learning. Ballimore: Paul H. Brookes. Amado, A. N. (1993). Friendships and community connections between people with and without developmental disabilities. Baltimore: Paul Brookes.

Anderson, L., \& Heyne, L. (2000). A statewide assessment using focus groups: Perceived challenges and goals in providing inclusive recreation services in rural communitics. Journal of Park and Recreation Administration, 18, 17-37.

Barberich, K. (2001, July 1). Caring makcs couple special. Fresno Bee, p. E1.

Bates, P., Morrow, S., Pancsofar, E., \& Sedlak, R. (1984). The effect of functional versus non-functional activities on the attitudes/expectations of non-handicapped persons: What they see is what we get. Journal of the Association for Persons with Severe Handicaps, 9, 73-78.
Blaska, J. (1993). The power of languagc: Spcak and write using "person first." In M. Nagler (Ed.). Perspectives on disability (2nd cd. pp. 25-32). Palo Alto. CA: Health Markets Rescarch.

Block, M. E.. \& Moon, M. S. (1992). Orelove, Wehman, and Wood revisited: An evaluative review of Special Olympics ten years later. Education and Training in Mental Retardation, 27 , 379386.

Bogdan, R., \& Biklen, D. (1977). Handicapism. Social Policy, 7 , 59-63.

Bogdan, R., \& Knoll, J. (1995). The sociology of disability. In E. L. Meyen \& T. M. Skirtic (Eds.), Special education and student disability (pp. 675-711). Denver, CO: Love Publishing Company.

Bombeck, E. (1987, September 17). Special Olympians make valiant efforts. Los Angeles Times Syndicate.

Bricaddy, F. (1993, June 20). Olympians run and jump for joy. Syracuse Herald American, pp. C1-C2.

Browder, D. M., Cooper, K., \& Lim, L. (1998). Teaching adults with severe disabilitics to express their choice of settings for leisure activities. Education and Training in Mental Retardation and Developmental Disabilities, 33, 226-236.

Brown, F., Evans, I. M., Weed, K. A., \& Owen, V. (1987). Delineating functional compctencics: A component model. Journal of the Association for Persons with Severe Handicaps, 12, 117-124.

Brown, L., Branston, M. B., Hamre-Nietupski, S., Pumpian, 1., Certo, N., \& Gruencwald, L. (1979). A strategy for developing chronological age-appropriate and functional curricular content for severely handicapped adolescents and young adults. Journal of Special Education, 13, 81-90.

Brown, L., Nietupski, J., \& Hamre-Nietupski, S. (1976). Criterion of ultimate functioning. In M. A. Thomas (Ed.), Hey, don't forget about me! (pp. 2-15). Reston, VA: Council for Exceptional Children.

Brundige, T. L., Hautala, R. M., \& Squircs, S. (1990). The Special Olympics developmental sports program for persons with severe and profound disabilities: An assessment of its cffectiveness. Education and Training in Mental Retardation, 25, 376-380.

Burns, M., Storey, K., \& Certo, N. J. (1999). The effect of service learning on attitudes towards students with scvere disabilities. Education and Training in Mental Retardation and Developmental Disabilities, 34, 58-65.

Butterworth, J, Fesco, S. L., \& Ma, V. (2000). Because it was the right thing to do: Changeover from facility-based services to community cmployment. Journal of Vocational Rehabilitation, 14, 23-35.

Calhoun, M. L., \& Calhoun, L. G. (1993). Age-appropriate activitics: Effects on the social perception of adults with mental retardation. Education and Training in Mental Retardation. $28,143-148$.

Callahan, M., \& Mank, D. (1998). Choice and control of employment for people with disabilities: A white paper. In T. Nerny \& D. Shumway (Eds.). The importance of income (pp. 15-33). Durham, NH: University of New Hampshire.

Cartcr, E. W., \& Hughes, C. (2007). Social interaction interventions: Promoting socially supportive environments and teaching new skills. in S. L. Odom, R. H. Horner, M. E. Snell, \& J. Blacher (Eds.), Handbook of developmental disabilities (pp. 310-329). New York: Guilford.

Chadsey, J. (2007). Adult social relationships. In S. L. Odom, R. H. Horner, M. E. Snell, \& J. Blacher (Eds.), Handbook of developmental dixabilities (pp, 449 466). New York: Guilford.

Charlton, J. I. (1997). Nothing about us without us: Disability oppression and empowerment. Bcrkclcy, CA: University of California Press.

Cowles, A. (1998, April 9). Bencfit earns Special Olympics funds. The Atlanta Constitution, $X J 1,1$. 
Crissey, M. S., \& Rosen, M. (1986). Institutions for the mentally retarded: A changing role in changing times. Austin, TX: Pro-Ed.

Dattilo, J. (2008). Leisure education program planning: $A$ systematic approach (3rd ed.). State College, PA: Venture.

DePalma, A. (1997, February 10). Special winter games warm hearts in Toronto. The New York Times, p. A6.

Devine, M. A., McGovern, J. N., \& Hermann, P. (1998). Inclusion in youth sports. Journal of Park and Recreation Administration, $17,56-72$.

DiLeo, D. (1994). Reaching for the dream: Developing individual service plans for persons with disabilities. St. Augustine, FL: Training Resources Network.

DiLeo, D. (2007). Raymond's room: Ending the segregation of people with disabilities. St. Augustine, FL: Training Resources Network.

Dykens, E. M., \& Cohen, D. J. (1996). Effect of Special Olympics International on social competence in persons with mental retardation. Joumal of the American Academy of Child and Adolescent Psychiatry, 35, 223-229.

Ellis, B. C. (1989, March 5). Great! No. 199 finds his spot. The Oregonian, p. B2.

Felce, D. (1997). Defining and applying the concept of quality of life. Joumal of Intellectual Disability Research, 41, 126-135.

Felce, D., \& Perry, J. (2007). Living with support in the community: Factors associated with quality-of-life outcome. In S. L. Odom, R. H. Horner, M. E. Snell, \& J. Blacher (Eds.), Handbook of developmental disabilities (pp. 410-428). New York: Guilford.

Fleischer, D. Z., \& Zames, F. (2001). The disability rights movement: From charity to confrontation. Philadelphia: Temple University Press.

Ford, A., \& Davern, L. (1989). Moving forward with school integration: Strategies for involving students with severe handicaps in the life of the school. In R. Gaylord-Ross (Ed.), Integration strategies for students with handicaps (pp. 11-31). Baltimore: Paul H. Brookes.

Garcia, L. A., \& Menchetti, B. M. (2003). The adult lifestyles planning cycle: A continual process for planning personally satisfying adult lifestyles. In D. L. Ryndak \& S. Alper (Eds.) Curriculum and instruction for students with significant disabilities in inclusive settings (pp. 277-306). Boston: Allyn and Bacon.

Gardiner, L. (1998, May 3). Special Olympics' athletes win smiles: Races belong to not-so-swift, not-so-strong. The Oakland Tribune, p. B1.

Gillespie, M. (2008). Participation patterns in an urban Special Olympics programmc. British Joumal of Leaming Disabilities, 37, 21-27.

Hagner, D. (2000). Supporting people as part of the community: Possibilities and prospects for change. In J. Nisbet \& D. Hagner (Eds.), Part of the community: Strategies for including everyone (pp. 15-42). Baltimore: Paul Brookes.

Hanley-Maxwell, C., Rusch, F. R., Chadsey-Rusch, J., \& Renzaglia, A. (1986). Reported factors contributing to job termination of individuals with severe disabilities. Joumal of the Association for Persons with Severe Handicaps, 11, 45-52.

Harada, C. M., \& Siperstein, G. N. (2009). The sport experience of athletes with intellectual disabilities: A national survey of Special Olympics athletes and their families. Adapted Physical Education Quarterly, 26, 68-85.

Heshusius, L. (1984). Why would they and I want to do it? A phenomenological-theoretical view of special education. Learning Disabilities Quarterly, 7, 363-368.

Hourcade, J. J. (1989). Special Olympics: A review and critical analysis. Therapeutic Recreation Journal, 23, 58-65.

Johnson, M. (2003). Make them go away: Clint Eastwood, Christopher Reeve \& the case against disability rights. Louisville, KY: Advocado Press.

Klein, T., Gilman, E., \& Zigler, E. (1993). Special Olympics: An cvaluation by professionals and parents. Mental Retardation, $31,15-23$.

Kozub, F. M., \& Lienert, C. (2003). Attitudes toward teaching children with disabilities: Review of literature and research paradigm. Adapted Physical Activity Quarterly, 20, 323-346.

Kozub, F. M., \& Porretta, D. (1996). Including athletes with disabilities: Interscholastic benefits for all. Journal of Physical Education, Recreation and Dance, 67, 19-24.

Lampkin, L. M. (2006). You're paying what? How to set executive compensation. The Nonprofit Quarterly, 13, 44-48.

Lipsky, D., \& Gartner, A. (1997), Inclusion and school reform: Transforming America's classrooms. Baltimore: Paul Brookes.

Longmore, P. (1985). A note on language and the social identity of disabled people. American Behavioral Scientist, 28, 419-423.

Lord, M. A., \& Lord, W. J. (2000). Effects of the Special Olympics of Texas athletes for outreach program on communication competence among individuals with mental retardation. Communication Education, 49, 267-283.

Mank, D. (2007). Employment. In S. L. Odom, R. H. Horner, M. E. Snell, \& J. Blacher (Eds.), Handbook of developmental disabilities (pp. 391-409). New York: Guilford.

Mank, D. M., \& Buckley, J. (1989). Strategies for integrating employment environments. In W. Kicrnan \& R. Schalock (Eds.), Economics, industry, and disability: $A$ look ahead (pp. 319-335). Baltimore: Paul H. Brookes.

Martin, D. (1995, July 2). I may not be a victor, but let me try bravely: Special Olympians give games their all. The New York Times, p. 30.

McDonnell, J., Mathot-Buckner, C., \& Ferguson, B. (1996). Transition programs for students with moderate/severe disabilities. Pacific Grove, CA: Brooks/Cole.

Mellon, S. (2000, May 13). Special hug. The Pittsburgh Press, p. Al.

Modell, S. J., \& Valdez, L. A. (2002). Beyond bowling: Transition planning for students with disabilities. Teaching Excep. tional Children, 34, 46-52.

Moon, S. (1994). Making school and community recreation fun for everyone: Places and ways to integrate. Baltimore: Paul Brookes.

Newton, J. S., Olson, D., Horner, R. H., \& Ard, W. R. (1996). Social skills and the stability of social relationships between individuals with intellectual disabilities and other community members. Research in Developmental Disabilities, 17, 15-26.

Ninot, G., Bilard, J., \& Sokolowski, M. (2000). Athletic competition: A means of improving the self-image of the mentally retarded adolescent? International Journal of Rehabilitation Research, 23, 111-117.

Orelove, F. P., \& Moon, M. S. (1984). The Special Olympics program: Effects on retarded persons and society. Arena Review, $8,41-45$

Orelove, F. P., Wehman, P., \& Wood, J. (1982). An evaluative review of Special Olympics: Implications for community integration. Education and Training of the Mentally Retarded, 17 . 325-329.

Polloway, E. A., \& Smith, J. D. (1978). Special Olympics: A second look. Education and Training of the Mentally Retarded, 13, 432-433.

Polloway, E. A., Smith, J. D., Patton, J. R., \& Smith, T. E. C. (1996). Historic changes in mental retardation and developmental disabilities. Education and Training in Mental Retardation and Developmental Disabilities, 31, 3-12.

Porretta, D. L., Gillespic, M., \& Jansma, P. (1996). Perceptions about Special Olympics from service delivery groups in the United States: A preliminary investigation. Education and Training in Mental Retardation and Developmental Disabilities, $31,44-54$.

Rice, T., \& Fleck, L. (1988). Moving into the 90s with TASH and the Special Olympics. TASH Newsietter, 14, 12.

Rogan, P., Banks, B., \& Howard, M. (2000). Workplace supports in practice: As little as possible, as much as necessary. 
Focus on Autism \& Other Developmental Disabilitiex, 15 , 2-12.

Roper, P. (1990a). Changing perceptions through contact. Disability, Handicap and Society, 5, 243- 255.

Roper, P. (1990b). Special Olympics volunteers' perceptions of people with mental retardation. Education and Training in Mental Retardation, 25, 164-175.

Schleien, S. J., Green, F. P., \& Heyne, L. A. (1993). Integrated community recreation. In M. E. Snell (Ed.), Instruction of students with severe disabilities (pp. 526-555). Columbus, $\mathrm{OH}$ : Merrill.

Schleien, S. J., \& Meyer, L. H. (1988). Community-based recreation programs for persons with severe developmental disabilities. In M. D. Powers (Ed.), Expanding systems of service delivery for persons with developmental disabilities (pp. 93-112). Baltimore: Paul Brookes.

Shapiro, J. P. (1993). No pity: People with disabilities forging a new civil rights movement. New York: Times Books.

Shaw, B. (1994). The ragged edge: The disability experience from the pages of the first fifteen years of the disability rag. Louisville, KY: The Advocado Press.

Shevin, M., \& Klein, N. (1984). The importance of choice-making skills for students with severe disabilities. Journal of the Association for Persons with Severe Handicaps, 9, 159166.

Siperstein, G. N., Glick, G. C., \& Parker, R. C. (2009). Social inclusion of children with intellectual disabilities in a recreational setting. Intellectual and Developmental Disabilities, 47, 97-107.

Smart, J. (2001). Disability, society, and the individual. Gaithersburg, MD: Aspen Publishers, Inc.

Smith, G. J., Edelen-Smith, P. J., \& Stodden, R. A. (1998). Effective practice for generating outcomes of significance: The complexities of transformational change. In A. Hilton \& R. Ringlaben (Eds.), Best and promising practices in devetopmental disabilities (pp. 331-342). Austin, TX: Pro-Ed.

Special Day for Special Kids. (1999, 18 November). The New Orleans Times-Picayune, p. 1G.

Storey, K. (1993). A proposal for assessing integration. Education and Training in Mental Retardation, 28, 279-287.

Storey, K. (1998). Telethons and the Special Olympics: Where does that moncy go? Some revelations and how to get more information. Ragged Edge, 19, 30-33.

Storey, K. (2004). The case against the Special Olympics. Journal of Disability Policy Studies, 15, 35-42.

Storey, K., Stern, R., \& Parker, R. (1990). A comparison of attitudes towards typical recreational activities versus the Special Olympics. Education and Training in Mental Retardation, $25,94-99$.

Stumbo, N. J., \& Peterson, C. A. (2009). Therapeutic recreation program design: Principles and procedures (5th ed.). New York: Pearson.

Surman, M. (1999, June 11). Shedding some light on winning: Special Olympics athletes and their supporters carry symbolic torch 79 miles through county en route to the summer games in Long Beach. The Los Angeles Times (Ventura County Edi(ion), p. B1.

Townscnd. M. \& Hassall, J. (2007). Mainstream students' attitudes to possible inclusion in unificd sports with students who have an intellectual disability. Journal of Applied Research in Intellectual Disubilities, 20, 265-273.

Turnbull, H. R., III, Stowe, M. J., Turnbull, A. P., \& Schrandt, M. S. (2007). Public policy and developmental disabilitics: A 3.5-year retrospective and a 5-year prospective based on the corc concepts of disability policy. In S. L. Odom, R. H. Horner, M. E. Snell, \& J. Blacher (Eds.), Handbook of devetopmental disabilities (pp. 15-34). New York: Guilford.

Vogel. B. H., \& Quatt, C. W. (2005). Dollars and sense: The nonprofit board's guide to determining chief executive compensation. Washington, DC: Boardsource.

Wehmeyer, M. L., Agran, M., \& Hughes, C. (1998). Teaching selfdetermination to youth with disabilities: Basic skills for successful trunsition. Baltimore: Paul Brookes.

Wciss, J. A., \& Bcbko, J. M. (2008). Participation in Special Olympics and change in athletc sclf-concept over 42 months. Journal on Developmental Disabilities, 14, 1-8.

Wilcox, B., \& Bellamy, G. T. (1982). Design of high school programs for severely handicapped students. Baltimore: Paul Brookes.

Wilhite, B., \& Kleiber, D. A. (1992). The effect of Special Olympics participation on community integration. Therapetutic Recreation Journal, 26, 9-20.

Will, M. (1984). Supported employment for adults with severe disabilities: An OSERS program initiative. Washington, DC: Office of Special Education and Rehabilitative Services.

Wolfensberger, W. (1995). Of normalization, lifestylcs, the Special Olympics, deinstitutionalization, mainstreaming, integration, and cabbages and kings. Mental Retardation, 33, $128-131$

Zhang. J., Gast, D., Horvat, M.. \& Dattilo, J. (1995). The effectiveness of a constant time delay procedure on tcaching lifetime sport skills to adolescents with severe to profound intellectual disabilities. Education and Training in Mental Retardation and Developmentat Disabilities, 30, 51-64.

Received: May 14, 2009

Final Acceptance: May 14, 2009

Editor in Charge: Martin Agran 


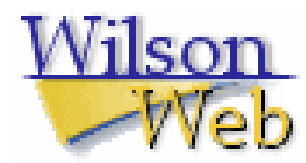

\section{COPYRIGHT INFORMATION}

TITLE: The More Things Change, the More They Are the Same: Continuing Concerns With the Special Olympics

SOURCE: Res Pract Pers Severe Disabil 33 no3 Fall 2008

The magazine publisher is the copyright holder of this article and it is reproduced with permission. Further reproduction of this article in violation of the copyright is prohibited. 